\title{
The Analysis of Company Size, Complexity of Operation, Profitability, Solvency and Audit Firm Size toward Timeliness of Financial Statement Reporting for Company listed in LQ45 Index in Indonesia Stock Exchange (2012 - 2014)
}

\author{
Raditya Pratama \\ radittama14@gmail.com \\ Accounting Study Program, Faculty of Business \\ Universitas Presiden, Cikarang, Indonesia \\ Monika Kussetya Ciptani \\ monique@president.ac.id \\ Accounting Study Program, Faculty of Business \\ Universitas Presiden, Cikarang, Indonesia
}

\begin{abstract}
Companies are required to submit their annual report timely after the end of fiscal year to support stakeholder's need of information. Financial statements would have benefits if delivered accurately and timely to the users for decision making. This research is aimed to identify the effect of company size, complexity of operation, profitability, solvency, and audit firm size toward the timeliness of financial statements reporting in companies that are listed in LQ45 index from 2012 to 2014 either simultaneously and partially. The research involves 69 samples, which consist of 3 years data of 23 companies that are consistently listed in LQ45 index from 2012 to 2014. The research found that complexity of operation, profitability, and audit firm size are statistically significant toward the timeliness of financial statements reporting. While company size and profitability are not statistically significant toward the timeliness of financial statements reporting. The F-test result revealed that one or more independent variables have significant influence toward the timeliness of financial statements reporting. Then, the $\mathrm{R}^{2}$ analysis showed that the regression model is able to describe timeliness of financial statements reporting by $26.3 \%$. The rest $73.7 \%$ is explained by other factors apart from this research.
\end{abstract}

Keywords: timeliness, company size, complexity of operation, profitability, solvency, audit firm size 


\title{
The Analysis of Company Size, Complexity of Operation, Profitability, Solvency and Audit Firm Size toward Timeliness of Financial Statement Reporting for Company listed in LQ45 Index in Indonesia Stock Exchange (2012 - 2014)
}

\author{
Raditya Pratama \\ radittama14@gmail.com \\ Accounting Study Program, Faculty of Business \\ Universitas Presiden, Cikarang, Indonesia \\ Monika Kussetya Ciptani \\ monique@president.ac.id \\ Accounting Study Program, Faculty of Business \\ Universitas Presiden, Cikarang, Indonesia
}

\section{Intisari}

Perusahaan wajib mengirim laporan keuangan tepat waktu setelah tahun fiskal berakhir untuk mendukung kebutuhan informasi pemangku kepentingan. Laporan keuangan akan bermanfaat jika dapat disajikan secara akurat dan tepat waktu kepada pihak yang membutuhkan untuk pengambilan keputusan. Penelitian ini bertujuan untuk mengidentifikasi pengaruh ukuran perusahaan, kompleksitas operasi, profitabilitas, solvency and ukuran kantor akuntan publik terhadap ketepatan waktu pelaporan laporan keuangan pada perusahaan-perusahaan yang terdaftar di indeks LQ-45 dari tahun 2012 sampai dengan 2014, baik secara simultan maupun secara parsial. Penelitian ini melibatkan 69 sampel yang meliputi data 3 tahun dari 23 perusahaan yang secara konsisten terdaftar di indeks LQ-45 dari tahun 2012-2014. Hasil penelitian menunjukkan bahwa kompleksitas operasi, profitabilitas dan ukuran kantor akuntan publik secara statistik signifikan mempengaruhi ketepatan waktu pelaporan laporan keuangan. Sedangkan ukuran perusahaan dan profitabilitas secara statistik tidak signifikan terhadap ketepatan waktu pelaporan laporan keuangan. Uji F menyatakan bahwa satu atau lebih variabel bebas memiliki pengaruh signifikan terhadap ketepatan waktu pelaporan laporan keuangan. Sedangkan analisis $\mathrm{R}^{2}$ menunjukkan bahwa variabel-variabel pada model regresi $26.3 \%$ dapat menjelaskan ketepatan waktu pelaporan laporan keuangan, sisanya $73.3 \%$ dijelaskan oleh faktor-faktor lain yang tidak dibahas dalam penelitian ini.

Keywords: ketepatan waktu, ukuran perusahaan, kompleksitas operasi, profitabilitas, solvency, ukuran kantor akuntan publik 


\section{INTRODUCTION}

The timeliness of financial reporting is needed by the investors to do analysis on the capital that have been invested or will be invested in a company (Al Daoud et al., 2014). It means that the timeliness of financial statements reporting is a factor attracting the investors to invest in a company. Timely reporting also contributes to the prompt and efficient performance of stock markets and to mitigate (or reduce the level of) insider trading, leaks, and rumors in the market (Owusu-Ansah, 2000). The company that publish their financial statements faster than others will be seen first by the investors, because the investors want to know the financial information of a company and the reliable source of information available to them. The delay of financial statement reporting will cause a negative reaction from investors. It means that investors do not need the information anymore because their decisions have already been made (Bonson \& Borrero, 2011).

The timeliness of financial reporting in Indonesia has been regulated by Badan Pengawas Pasar Modal dan Lembaga Keuangan (Bapepam \& LK). "Laporan keuangan tahunan wajib disertai dengan laporan Akuntan dalam rangka audit atas laporan keuangan. Laporan keuangan tahunan wajib disampaikan kepada Bapepam dan LK dan diumumkan kepada masyarakat paling lambat pada akhir bulan ketiga setelah tanggal laporan keuangan tahunan" (Keputusan Ketua Bapepam \& LK No.: Kep-346/BL/2011). It means that public company have to submit and publish the financial statement no later than the end of third months after financial statement date. The financial statement also have to be accompanied by independent auditor's report/opinion. Although there is a sanction to the companies who were late in reporting the financial statement, but in fact, still there are companies that were late in reporting the financial statement (Kep-307/BEJ/07-2004 No. I-H). In 2012 there are total of 52 companies, in 2013 there are total of 49 companies, and in 2014 there are total of 52 companies that late in reporting their financial statement.

In order to help investors in generating investment decision in capital market, Indonesia capital market launched LQ45 Index. LQ45 Index is a market capitalization-weighted index that captures the performance of 45 most liquid companies listed on the Indonesia Stock Exchange (IDX). The index comprises of 45 stocks choice based on their liquidity, market capitalization and other criteria. The LQ45 Index covers at least 70\% of the stock market capitalization and transaction values in the capital market. Hence, LQ45 index is able to reflect the performance of companies' listed shares in Indonesia Stock Exchange. In this research, author is interested in finding out the factors affecting the timeliness of financial statement reporting of the company listed in IDX especially the company in LQ45 index. Using the previous research as the reference in conducting the research, author will make a research to the factors such as company size, complexity, profitability, solvency, and audit firm that affecting financial statement reporting timeliness.

This research will discuss about the timeliness of financial statement reporting in the company listed in LQ45 index of Indonesia Stock Exchange. The companies that will be tested only those that consistently listed in LQ45 index for 3 years straight, from 2012, 2013, and 2014. The factor that affecting the timeliness will focus on the company size, complexity of company, profitability, solvency, and size of audit firm.

\section{LITERATURE REVIEW}

One of the attributes that can be connected with the timeliness of financial statements 
reporting is the company size. The size of the company can be assessed from several aspects. It can be based on the total value of assets, total sales, market capitalization, the amount of labor, and so on. The greater the value of these items, the greater the size of the company. Large companies shows that there is a lot of information that is contained in the company. Large companies often argue to be faster in submit their financial statements for several reasons. First, large companies have more resources, more accounting staff, sophisticated information systems, and have a good internal control system. Second, large companies receive more supervision from investors and regulators. In detail, large companies often followed by a large number of analysts who always expect timely information to strengthen and revise their expectations. Large companies are under pressure to announce its financial report on time to avoid any speculation in their companies stock trading (Owusu-Ansah, 2000). Other than that large companies will also be highlighted by the public than smaller companies. Therefore, large companies will attempt to submit their financial statements timely to maintain its image in the public (Dyer \&Mc Hugh, 1975).

The level of complexity of operation in a company depends on the number and location of its operating units (branches) as well as the diversification of product lines and markets. These things is more likely to affect the time required auditors to complete the audit work. So it also affects the timeliness of the company's financial statements reporting to the public. That relationship is also supported by research Ashton et.al. (1987) in Owusu-Ansah (2000) who found that there is a positive correlation between the complexities of company's operating to the audit delay. Furthermore, research conducted by Owusu-Ansah (2000) found empirical evidence that the level of complexity of the operation of a company has a relationship that will affect the company's timeliness in submitting financial statements to the public.

Financial performance information, especially the profitability is required to assess potential changes in the economic resources that may be controlled in the future. Profitability is also used as an indicator to determine the successfulness of the company's performance to generate profit. The higher the profitability of a company then financial statements produced by the company contain good news. Companies that have good news in their report is likely to be more timely in publishing the financial statements. On the other hand, companies that have a low level of profitability then the financial statements will contain the bad news. Companies that have bad news in their report will likely not timely in publishing the financial statements. This conform with the previous research conducted by several researchers. Based on research conducted by Dyer and McHugh (1975), found that companies that earn profits tend to be timely in submitting their financial statements, and vice versa if loss. While Carslaw and Kaplan (1991) found that companies experiencing losses ask auditors to schedule the audit slower than it should, as the result becomes late in submitting their financial statements.

Solvency is the ability of the company to settle all liabilities. According Carslaw and Kaplan (1991), the relative proportion of debt to total assets indicates a company's financial condition. Greater proportion of debt to total assets increases the likelihood of loss and may increase caution auditor on the financial statements to be audited. This is due to the high proportion of debt will increase the risk of losses. Therefore, companies that have unhealthy financial condition are usually prone to mismanagement and fraud. The high debt to equity ratio reflects the company's high financial risk. The company's high financial risks indicates that the company is experiencing financial distress due to high liabilities. Financial distress of company is bad news which would affect the company in the public view. The management will tend to delay the submission of financial statements that contained bad news because the time available will be used to suppress the debt to equity ratio as low as possible.

A financial statement or information of company's performance should be presented 
accurately and reliable. Hence, the company then used the services of a public accounting firm to carry out audit work on the financial statements of the company. The size of the public accounting firm is differentiated into public accounting firms that enter the top four, in this case the Big Four and non Big Four public accounting firms, where the big four public accounting firm tend to more quickly complete the audit task they received. Big Four public accounting firms generally have greater resources so that it can conduct audits more quickly and efficiently. This proves the opinion that companies audited by a Big Four public accounting firm tend to more quickly complete the audit when compared with companies audited by a non Big Four public accounting firm.

\section{RESEARCH METHOD}

The research method used is a quantitative method. In this research, the dependent variable is timeliness of financial statement reporting. Independent variable is variable that explain or affect the function of other variable. There are five independent variables used, which are size of company, complexity of operation, profitability (return on assets), solvency (debt to equity), and audit firm size.

This research will examine the effect of independent variable to dependent variable using multiple regression model. Operational definition is an indicator of how the variables are measured. To simplify the analysis, each variable will be defined operationally.

\section{Timeliness}

Timeliness is the span of the announcement of audited annual financial statements to public which is the length of days required to announce the annual financial statements which have been audited to the public, since the company's fiscal year closing date (December 31) until the date of submission to Otoritas Jasa keuangan (OJK) (no later than March 31 next year). This dependent variable is measured based on the date of submission of the audited annual financial statements.

\section{Company Size}

The size of the company can be expressed on the total value of assets, total sales, market capitalization, and so on. The greater the value of the items, the greater the size of the company. In this research, the size of the company is proxied by using Ln market capitalization. Market capitalization is the aggregate valuation of the company based on its current share price and the total number of outstanding share. The use of natural logarithm $(\mathrm{Ln})$ in this research are intended to reduce excessive fluctuations in the data. If we use market capitalization value originally from company data, the value of variable will be huge in amount maybe billions or even trillions. By using natural logs, the value of billions and even trillions can be simplified, without changing the proportions of the value of the actual origin.

\section{Complexity of Operation}

It is expected that the degree of complexity of a company's operations will influence how timely the company reports to the public. The degree of complexity of a company's operations which depends on the number and locations of its operating units (branches), diversification of its product lines and market. These complexity is more likely to affect the time auditor takes to complete his/her audit assignment, and hence, the time by which the company will eventually release its financial report to the public. Thus, a positive relationship between operational complexity and audit delay is expected. The complexity of a company's operations is captured by the number of subsidiaries in which a sample company operates. 


\section{Profitability}

Profitability is an indicator of the success of the company (management effectiveness) in generating profits. The higher the company's ability to generate profits, the higher the level of effectiveness of the company's management. Profitability can be measured using the net profit margin by:

$$
\text { Net Profit Margin }=\text { Net Sales } \text { i.t } / \text { Net Income after Tax } \text { i.t }
$$

Where

Net Sales i.t $_{\text {N }} \quad=$ Net Sales of company $\mathrm{i}$ in year $\mathrm{t}$

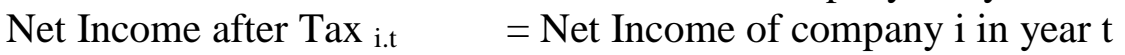

\section{Solvency}

Solvency is the company's ability to pay off its debts both long-term debt and short-term debt. In this research, measured using a solvency ratio of total debt to total assets, or the socalled debt to total assets ratio.

\section{Debt to Total Assets = Total Liabilities $/$ Total Assets}

\section{Audit Firm Size}

In this research, the size of audit firm is measured by looking at which audit firm audits the company's financial statements. There are two categories of audit firms, Big four and non Big four. The Big Four are the four largest international public accounting firm. Audit firms that categorized as Big Four are PwC, Deloitte, EY, and KPMG. Audit firms size in this research is measured by using a dummy variable, for companies that use the services of the firm that partnered with Big Four audit firms coded 1 and for companies that use the services of the firm that is not partnered with Big Four audit firms coded 0.

\section{Sampling Design}

The sample represents the population that has similar characteristics and can be considered. In this research, the sample is taken by purposive sampling method; the sample is selected by applying criterias. The sample is taken from companies in LQ45 index in Indonesian Stock Exchange (IDX) for period 2012 - 2014. The criterias applied in this research are:

1. Companies that still actively listed in the IDX specifically in LQ45 Index companies for the period of $2012-2014$.

2. Companies that consistently listed in the IDX specifically in LQ45 Index companies for the period of $2012-2014$.

3. The companies use rupiah (IDR) for financial reporting for the period of 20122014.

4. The companies which has earning after tax for the period of $2012-2014$.

5. The companies present the financial statements in accordance of the variables used in this research.

\section{RESEARCH METHOD}

Data analysis method that is applied in this research is a multiple regression analysis. Multiple regressions model will be used in this research to analyze the effect of independent 
variable to the dependent variable. The model is:

$$
\mathrm{TIME}_{i . t}=\beta \mathrm{o}+\beta 1 \mathrm{SIZE}_{i . t}+\beta 2 \mathrm{COMP}_{i . t}+\beta 3 \mathrm{PROF}_{i . t}+\beta 4 \mathrm{SOLV}_{i . t}+\beta 5 \mathrm{AUDIT}_{i . t}+\mathrm{e}
$$

Where:

Time $_{i, t}=$ timeliness of financial statement reporting in company $\mathrm{i}$ in year $\mathrm{t}$

Size $_{\mathrm{i}, \mathrm{t}} \quad=$ company size $\mathrm{i}$ in year $\mathrm{t}$

Comp $_{\mathrm{i}, \mathrm{t}} \quad=$ complexity of Operation in company $\mathrm{i}$ in year $\mathrm{t}$

Prof $_{\mathrm{i}, \mathrm{t}} \quad=$ profitability in company $\mathrm{i}$ in year $\mathrm{t}$

Solv $_{\mathrm{i}, \mathrm{t}} \quad=$ solvency in company $\mathrm{i}$ in year $\mathrm{t}$

Audit ${ }_{i, t} \quad=$ audit firm size in company $\mathrm{i}$ in year $\mathrm{t}$

B0 $\quad$ constanta

B1- $\beta 5=$ regression coefficients

e $\quad=$ error

\section{R-test}

Correlation coefficient test was used to determine the relationship between two independent and dependent variables, whether perfect, strong, moderate, weak, or do not have a relationship (Ghozali, 2013). This applies to interpret the correlation value zero means no relationship at all or close to 0 means that the relationship between the variables is weak, and said to be strong if $\mathrm{R}$ is close to 1 (Ghozali, 2013).

\section{Coefficient of Determination $\left(R^{2}\right.$ test $)$}

Coefficient of determination $\left(\mathrm{R}^{2}\right)$ is used to measure the variance of the dependent variable about its mean that is explained by the independent, or predictor, variables. The coefficient of determination is the square of the correlation $(\mathrm{r})$ between predicted $\mathrm{y}$ scores and actual $\mathrm{y}$ scores. Adjusted $\mathrm{R}^{2}$ always takes on a value between 0 and 1 . With linear regression, the coefficient of determination is also equal to the square of the correlation between $\mathrm{x}$ and $\mathrm{y}$ scores. The closer adjusted $\mathrm{R}^{2}$ is to 1 , the better the estimated regression equation fits or explains the relationship between $\mathrm{X}$ and $\mathrm{Y}$. An $\mathrm{R}^{2}$ of 0 means that the dependent variable cannot be predicted from the independent variable. An $\mathrm{R}^{2}$ of 1 means the dependent variable can be predicted without error from the independent variable. An $R^{2}$ between 0 and 1 indicates the extent to which the dependent variable is predictable.

\section{F-Test}

F-test is used to determine if the independent variables affecting the dependent variable simultaneously or not. Degree of confidence used is $5 \%$. If the significant test is greater than 0.05 , then the independent variables do not significantly affect the dependent variable at all. On the other hand, if the significant test is less than 0.05 , then it can be concluded that at least one of the independent variables do affect the dependent variable significantly in statistic.

The hypotheses for F-test are:

H0. : $\beta 1=\beta 2=\beta 3=\beta 4=\beta 5=0$

Ha.: $\beta \mathrm{i} \neq 0, \mathrm{i}=1,2,3,4,5$

At least one of the $\beta \neq 0$

t-Test 
t-test is used to determine if the independent variables partially affecting the dependent variable significantly in statistic. t-test can be done by looking the t-value and result of each level of significant. Degree of confidence used is $5 \%$. The variable does not statistically have significant impact, if the significant test is greater than 0.05 . Otherwise, if the significant test is less than 0.05 , then the variable does affect the dependent variable statistically significant. Followings are statistic notation of each hypothesis that will be tested through t-test.

The hypotheses for t-test are:

$\mathrm{HO}: \beta \mathrm{i}=0, \mathrm{i}=1,2,3,4,5,6$

Ha : $\beta \mathrm{i} \neq 0$

\section{RESULTS AND DISCUSSION}

\section{Descriptive Statistic Analysis}

Descriptive statistic is related to collection and rankings of data which describe the characteristics of sample used in this research. This analysis is to describe the characteristics of sample using extreme values (minimum and maximum value), mean (average), and standard deviation. Based on the data processed using SPSS which includes timeliness, company size, complexity of operation, profitability, and solvency it will be known the minimum value, maximum value, mean, and standard deviation of each variable.

While the audit firm size variable is not included in the calculation of descriptive statistics because audit firm size is a variable that has nominal scale. Nominal scale is a scale of measurement categories or groups (Ghozali, 2013). This figure only serves as a mere category labels without any intrinsic value, therefore it is not appropriate to calculate the value of the average (mean) and standard deviation of the variable (Ghozali, 2013).

Table 1. Descriptive Statistics

\begin{tabular}{lccccc}
\hline \multicolumn{1}{c}{ Variable } & N & Minimum & Maximum & Mean & Std. Deviation \\
\hline Timeliness & 69 & 23.00 & 96.00 & 69.2174 & 17.58414 \\
Company Size & 69 & 29.77 & 33.41 & 31.8183 & 0.95773 \\
Complexity of Operation & 69 & 1.00 & 44.00 & 10.6232 & 9.31176 \\
Profitability & 69 & 0.03 & 0.86 & 0.2262 & 0.16693 \\
Solvency & 69 & 0.14 & 0.88 & 0.5092 & 0.22738 \\
& & & & & \\
\end{tabular}

Source: Data processed 
According to Table 1, minimum value of timeliness variable is 23 and the maximum value is 96. It means that the shortest time for company to submit the audited financial statement is 23 days after the year end. Then the longest time for company to submit the financial statements is 96 days after the year end or not timely reported the financial statements. After that the average of Timeliness is 69.2174 and standard deviation 17.58414. The descriptive statistics also shows that the companies were timely reporting the financial statements with average 69 days.

Based on descriptive test in the Table 1 above, it can be known that minimum value of company size in the amount of 29.77; and maximum value 33.41. The result shows that the magnitude of market capitalization natural logarithm (ln) in this research range from 29.77 until 33.41 with average 31.8183 .

According to Table 1, minimum value of this variable is 1 and the maximum value is 44 . It means that at least the companies in this research have 1 subsidiary and the most subsidiaries that the company have is 44 . Then the average of subsidiaries is 10.6232 .

According to Table 1, minimum value of profitability in this research is 0.03 and the maximum value is 0.86 . It means that the least profitable sample is able to convert $3 \%$ of its revenue into profit. Meanwhile, the most profitable sample is able to convert $86 \%$ of its revenue into profit. The result shows that the magnitude of net profit margin in this research range from 0.03 until 0.86 with average 0.5092 .

According to Table 1, minimum value of solvency in this research is 0.14 and the maximum value is 0.88 . It means that the least solvent sample finance $14 \%$ of assets by using debt. Meanwhile the most solvent sample finance $88 \%$ of assets by using debt. The result shows that the magnitude of debt do total assets in this research range from 0.15 until 0.88 with average 0.5092 .

For a general overview of the sample with the audit firm size variable can be seen in the following frequency table:

Table 2. Audit Firm Size Data Description

\begin{tabular}{llcccc}
\hline & Frequency & Percent & $\begin{array}{c}\text { Valid } \\
\text { Percent }\end{array}$ & $\begin{array}{c}\text { Cumulative } \\
\text { Percent }\end{array}$ \\
\hline \multirow{2}{*}{ Valid } & Non Big & 9 & 13 & 13 & 13 \\
& Four & 60 & 87 & 87 & 100 \\
& Big Four & 69 & 100 & 100 & \\
& Total & &
\end{tabular}

Source: Data processed

Table 2 shows the frequency of samples using the service of Big Four or non Big Four audit firm for the period of 2012 until 2014. Based on the frequency table there are 9 samples $(13 \%)$ using the service using from non Big Four audit firm and there are 60 samples $(87 \%)$ using the service from Big Four audit firm.

\section{Result of Classical Assumption Test}

This research is intend to analyze the influence of company size, complexity of operation, profitability, solvency, and audit firm size toward audit delay in LQ45 index Indonesia Stock Exchange for period 2012-2014. Before doing regression analysis, the researcher do some classical assumption test. Classical assumption test is the main requirement in regression equation, so it must be tested against 4 classical assumption as 
follows : (1) normality test, (2) multicollinearity test, (3) heteroscedasticity test, (4) autocorrelation test. Result of classic assumption is presented below.

In this research, researcher used Kolmogorov-Smirnov to have more accurate and objective normality test. The researcher use this test instead of histogram graph because by only looking at the histogram, it can mislead the judgment, particularly for small size of sample (Ghozali,2013).

Table 3. One-Sample Kolmogorov-Smirnov Test Result

\begin{tabular}{llc}
\hline & & $\begin{array}{c}\text { Unstandardized } \\
\text { Residual }\end{array}$ \\
\hline N & Mean & 69 \\
& Std. Deviation & 0 \\
Most Extreme & Absolute & 15.09097729 \\
Differences & Positive & 0.109 \\
& Negative & 0.107 \\
Kolmogorov-Smirnov Z & & -0.109 \\
Asymp. Sig. (2-tailed) & & 0.907 \\
\hline
\end{tabular}

a. Test distribution is Normal.

b. Calculated from data.

Source: Data processed

Based on the Kolmogorov-Smirnov test in Table 3, the asymptotic significance is 0.383 . Asymptotic significance (2-tailed) $\geq$ alpha (0.05), hence the data is normally distributed.

The result of normality test also is completed with p-p plot graph that is presented below:

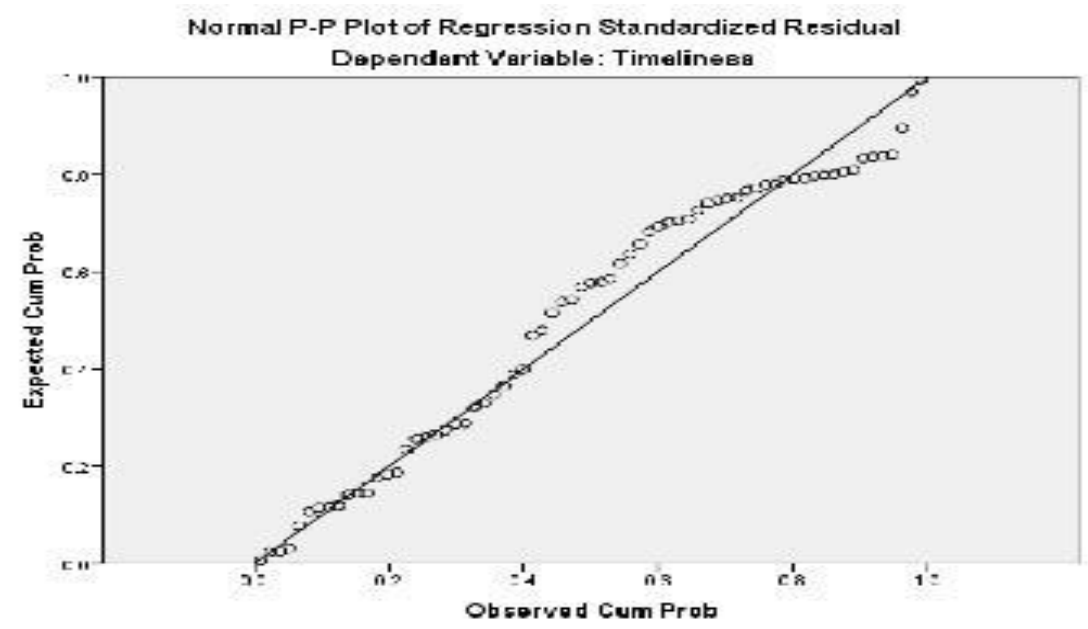

Figure 1. Probability Plot of Normality Test

Source: Data processed 
Based on Figure 1, the plot shows that the residual data is distributed normally since the dots pattern is following the diagonal line, which represents the normal distribution. Thus, it is shown that the residual value is distributed normally and independently.

Multicollinearity refers to a condition of collinearity between independent variables. Multicollinearity is a test to know if there is any collineaity or resemblance between independent variables, usually involves more than two independent variables. Multicollinearity can be detected by looking at the value of the tolerance and variance inflation factor (VIF). When the tolerance value is more than $0.10(>0.10)$ or VIF is less than $10(<10)$, it can be concluded there is no multicollinearity between the independent variables in the regression. The result of multicollinearity is shown in table below:

Table 4. Multicollinearity Test Result

\begin{tabular}{lllc}
\hline \multirow{2}{*}{ Model } & & \multicolumn{2}{c}{ Collinearity Statistics } \\
\cline { 3 - 4 } 1 & & Tolerance & VIF ' \\
\hline \multirow{4}{*}{} & (Constant) & & \\
& Company Size & 0.617 & 1.622 \\
& Complexity of & 0.888 & 1.126 \\
& Operation & 0.648 & 1.543 \\
& Profitability & 0.638 & 1.568 \\
& Solvency & 0.69 & 1.45 \\
\hline
\end{tabular}

Source: Data processed

The table above shows that all independent variable have tolerance value more than 0.10 $(>0.10)$ and VIF less than $10(<10)$. It can be concluded that there is no multicollinearity in this research regression linier model.

In this research to detect the presence or absence of heteroscedasticity is by looking at chart patterns generated from data processing using SPSS. The scatterplot graph below is used to analyze whether there is heteroscedasticity or homoscedasticity by observing the spread of dots.

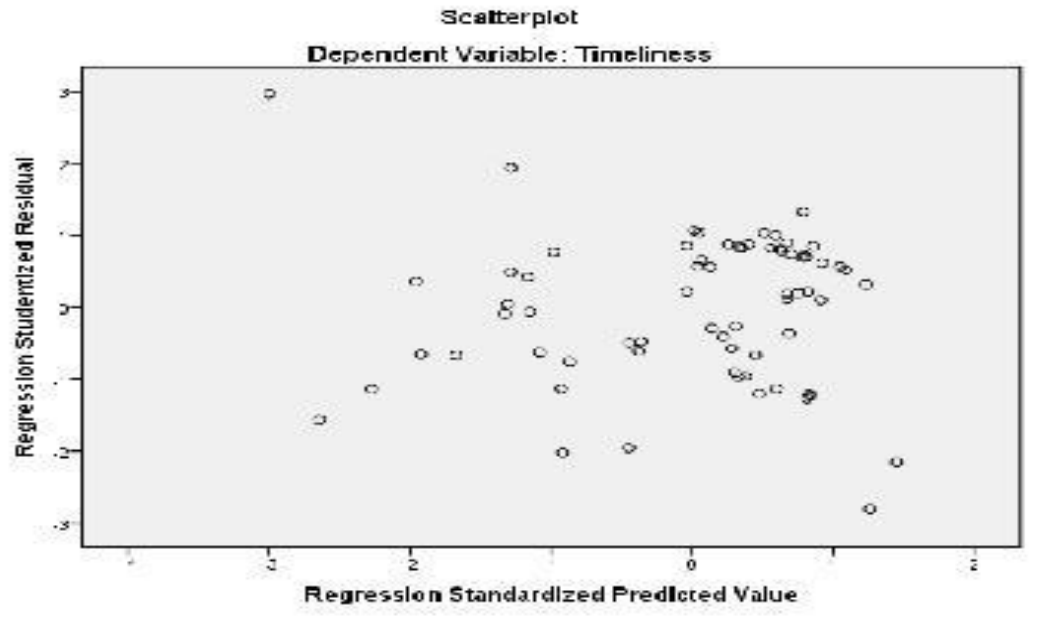

Figure 2. Scatterplot Graph of Heteroscedasticity Test Source: Data processed 
Scatterplot graph shows that the dots randomly spread and spread both above and below the number 0 on the $\mathrm{Y}$ axis, thus it can be concluded that there is no heteroscedasticity in the regression model. The existence of dots that spread away from the other dots due to the observation data is very different from any other observation data. To be more accurate, then Glejser test can be performed. This method regress absolute residual value to independent variable. There are two parameter to determine whether the heteroscedasticity exist with Glejser Test. The result of Glejser test is as follows:

Table 5. Glejser Test Result

\begin{tabular}{|c|c|c|c|c|c|}
\hline \multirow[b]{2}{*}{ Model } & \multicolumn{2}{|c|}{$\begin{array}{l}\text { Unstandardized } \\
\text { Coefficients }\end{array}$} & \multirow{2}{*}{$\begin{array}{c}\text { Standardized } \\
\text { Coefficients }\end{array}$} & \multirow[b]{2}{*}{$\mathbf{t}$} & \multirow[b]{2}{*}{ Sig. } \\
\hline & B & Std. Error & & & \\
\hline 1 (Constant) & -0.38 & 41.332 & & -0.009 & 0.993 \\
\hline SIZE & 0.454 & 1.393 & 0.05 & 0.326 & 0.746 \\
\hline COMP & -0.216 & 0.115 & -0.23 & -1.88 & 0.065 \\
\hline PROF & 6.885 & 7.532 & 0.133 & 0.914 & 0.364 \\
\hline SOLV & 5.003 & 6.002 & 0.126 & 0.834 & 0.408 \\
\hline AUDIT & -4.845 & 3.702 & -0.19 & -1.309 & 0.196 \\
\hline
\end{tabular}

Source: Data processed

Based on Glejser test which has been done in Table 5, it shows that none of the independent variable statistically significant influence Absolute Residual Value (ABS_RES) dependent variable. The Sig value of all independent variable is more than 0.05 ( $\mathrm{sig}>0.05$ ) which are $0.746 ; 0.065 ; 0.364 ; 0.408$; and 0.196 . Therefore, it can be concluded that the regression model does not contain any heteroscedasticity.

The researcher used Breusch-Godfrey test to detect autocorrelation test. Autocorrelation test aims to test whether the linear regression model in the development of a correlation between the disturbances error in period $t$ with disturbances error in period t-1 (Ghozali, 2013). If there is a correlation, there may be a problem of autocorrelation. Autocorrelation arises because sequential observations over time are related to each other. Good regression model is free from autocorrelation. The RES_2 value shows whether in a regression model occurs autocorrelation, with criteria if Sig RES_2 $\geq$ alpha (0.05), hence there is no autocorrelation or if Sig RES_2 $\geq$ alpha (0.05), hence there is autocorrelation. The result of Breusch-Godfrey test is as follows:

Table 6. Breusch-Godfrey Test Result

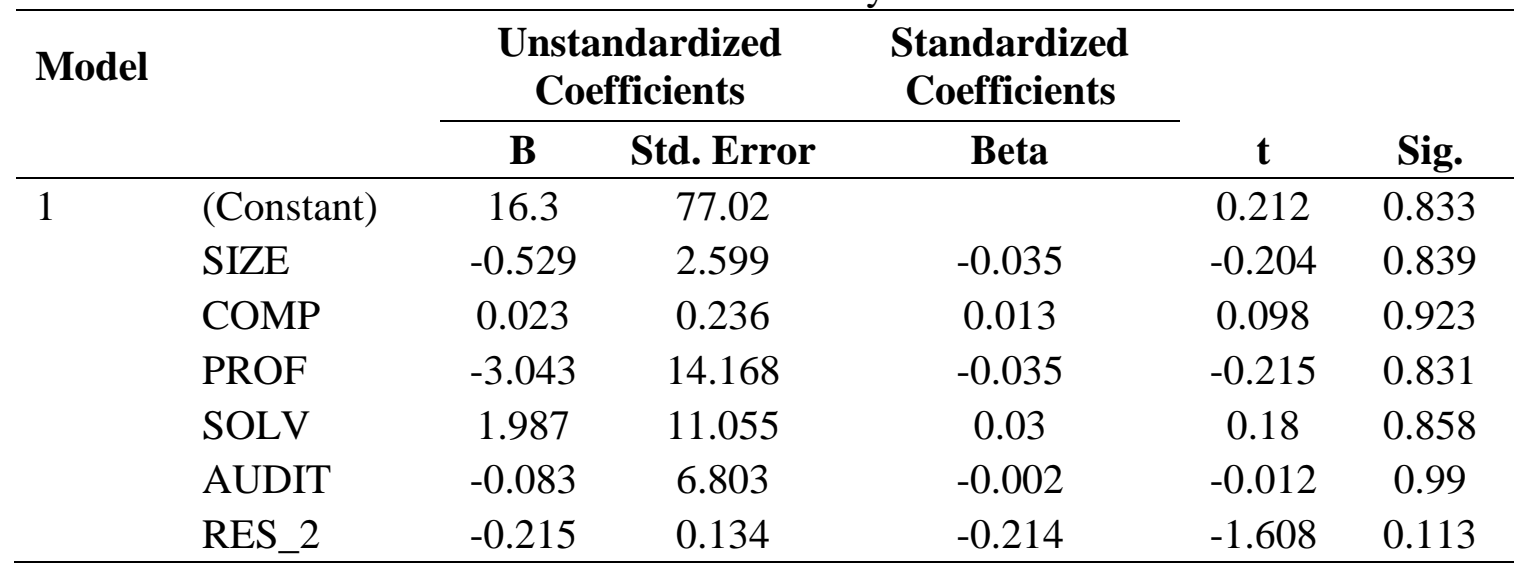

Source: Data processed 
According to Table 6, the significance value of RES_2 is 0.113 which is bigger than alpha $(\alpha=0,05)$. The significant value shows that there is no autocorrelation, then the data in this research is good to use.

\section{Result of R-Test}

Below is the result of correlation coefficient analysis (R-Test):

Table 7. R-Test Result

Model Summary ${ }^{\mathrm{b}}$

\begin{tabular}{lllll}
\hline Model & R & $\begin{array}{l}\text { R } \\
\text { Square }\end{array}$ & $\begin{array}{l}\text { Adjusted } \\
\text { R Square }\end{array}$ & $\begin{array}{l}\text { Std Error of } \\
\text { Estimate }\end{array}$ \\
\hline 1 & $.513^{\mathrm{a}}$ & 0.263 & 0.205 & 15.678 \\
\hline
\end{tabular}

a. Predictors: (Constant), AUDIT, COMP, PROF, SOLV, SIZE

b. Dependent Variable: TIME

Source: Data processed

According to Table 7 , the value of $\mathrm{R}$ is 0.513 , which is greater than 0.5 . The result shows that the relationship between independent variable and dependent variable is strong because it is between 0.5 and 1 .

\section{Coefficient of Determination $\left(\mathbf{R}^{2}\right.$ Test $)$}

The coefficient of determination (denoted by $\mathrm{R}^{2}$ ) is a key output of regression analysis. It is interpreted as the proportion of the variance in the dependent variable that is predictable from the independent variable. The coefficient of determination is the square of the correlation (r) between predicted y scores and actual y scores.

Table 8. Coefficient of Determination Test Result Model Summary ${ }^{\mathrm{b}}$

\begin{tabular}{|c|c|c|c|c|}
\hline Model & $\mathbf{R}$ & R Square & $\begin{array}{l}\text { Adjusted R } \\
\text { Square }\end{array}$ & $\begin{array}{l}\text { Std. Error } \\
\text { of the } \\
\text { Estimate }\end{array}$ \\
\hline 1 & $.513^{\mathrm{a}}$ & 0.263 & 0.205 & 15.678 \\
\hline
\end{tabular}

According to Table 8 , the value of $\mathrm{R}$ Square is 0.263 , which means that company size, complexity of operation, profitability, solvency and audit firm size are able to describe the timeliness of financial statements reporting by $26.3 \%$. The rest $73.7 \%$ is determined by variables other than all variables used in this research.

\section{Result of F-Test}

To see whether the regression model is a good model, and whether company size, complexity of operation, profitability, solvency, and audit firm size together influence timeliness of financial statements reporting, F test is conducted. F test is done to show the 
value of probability or significance in ANOVA that represents the appropriateness of the model of regression. The amount of the probability value is considered good if it is less than 0.05. Below is presented the result of $F$ test:

Table 9. F-Test Result

\begin{tabular}{llccccc}
\hline $\begin{array}{l}\text { ANOVA }^{\mathrm{b}} \\
\text { Model }\end{array}$ & & $\begin{array}{c}\text { Sum of } \\
\text { Squares }\end{array}$ & df & $\begin{array}{c}\text { Mean } \\
\text { Square }\end{array}$ & F & Sig. \\
\hline 1 & Regression & 5539.583 & 5 & 1107.917 & 4.507 & $.001^{\mathrm{a}}$ \\
& Residual & 15486.157 & 63 & 245.812 & & \\
& Total & 21025.739 & 68 & & & \\
\hline
\end{tabular}

a. Predictors: (Constant), AUDIT, COMP, PROF, SOLV, SIZE

b. Dependent Variable: TIME

Source: Data processed

From Table 9 above, Fstatistic value is 4.507 with significance ( $p$ value) of 0.001 . The significance value shows a result which is lower than significance level of $0.05(0.001<$ 0.05). With 5\% significance level, it shows that the F-table is 2.360. In comparison, the Fstatistic value of 5.507 is higher than the F-table value of 2.360 (4.507>2.360). From those results, it can be conclude that independent variables simultaneously contribute significant effect towards dependent variable or at least one of independent variables influences the dependent variable.

\section{Result of t-Test}

The hypotheses testing are performed through t-test. t-test is performed in order to analyze the extent of each independent variable's influence toward the dependent variable, which is the timeliness of financial statements reporting. In this research, the t-table (two tailed) used is 1.998 , which resulted from the degree of freedom of 63 (resulted from $69-5$ - 1) and $\alpha=5 \%$. The result of the t-test is shown in Table 10 below:

Table 10. t-test Result Coefficients $^{\mathrm{a}}$

\begin{tabular}{lcccccc}
\hline & & \multicolumn{2}{c}{$\begin{array}{c}\text { Unstandardized } \\
\text { Coefficients }\end{array}$} & $\begin{array}{c}\text { Standardized } \\
\text { Coefficients }\end{array}$ & & \\
\cline { 3 - 5 } Model & & B & $\begin{array}{c}\text { Std. } \\
\text { Error }\end{array}$ & Beta & t & Sig. \\
\hline 1 & (Constant) & 51.219 & 75.358 & & 0.68 & 0.499 \\
& SIZE & 1.67 & 2.528 & 0.091 & 0.66 & 0.511 \\
& COMP & -0.438 & 0.217 & -0.232 & -2.023 & 0.047 \\
& PROF & -38.022 & 14.146 & -0.361 & -2.688 & 0.009 \\
& SOLV & -19.455 & 10.472 & -0.252 & -1.858 & 0.068 \\
& AUDIT & -13.759 & 6.749 & -0.265 & -2.039 & 0.046 \\
\hline
\end{tabular}

a. Dependent Variable: TIME

Source: Data processed

From Table 10, the multiple linear regression equation will be:

$$
\begin{aligned}
\mathrm{TIME}=51.219+1.670 \mathrm{SIZE}- & 0.438 \mathrm{COMP}-38.022 \mathrm{PROF}-19.455 \mathrm{SOLV}- \\
& \text { 13.759AUDIT }
\end{aligned}
$$


The absolute value of timeliness (constant) is 51.219 when SIZE, COMP, PROF, SOLV, and AUDIT equal to zero (0). SIZE coefficient is 1.670 means every 1 point increase of company size, the length of time needed to report financial statement will increase by 1.670 days. COMP coefficient is -0.438 means every 1 point increase of complexity of operation, the length of time needed to report financial statement will decrease by 0.438 days. PROF coefficient is -38.022 means every 1 point increase of profitability, the length of time needed to report financial statement will decrease by 38.022 days. SOLV coefficient is -19.455 means every 1 point increase of solvency, the length of time needed to report financial statement will decrease by 19.455 days. AUDIT coefficient is -13.759 means every 1 point increase of solvency, the length of time needed to report financial statement will decrease by 13.759 days.

Meanwhile there are three variables that have significant influence on timeliness of financial statement reporting which are complexity of operation (COMP), profitability (PROF), and audit firm size (AUDIT). Below is presented the result of hypothesis testing.

SIZE $t$ statistic value is lower than $t$ table $(0.660<1.998)$ and the significance level is greater than $0.05(0.511>0.05)$. It means that there is no significant influence of SIZE toward timeliness of financial statements reporting for sample of LQ45 Index companies period 2012 - 2014. In this research, company size is measured by using market capitalization. Market capitalization is the aggregate valuation of the company based on its current share price and the total number of outstanding share. The share price of companies from different industry is vary because they have different market share. The sample taken in this research is coming from heterogeneous industries which resulting in discrepancy when comparing the company size by using market capitalization. This happened because there is disproportionate in market share of companies from different industry. Thus, market capitalization could not become the appropriate measurement to evaluate company size in this research and make the result has no significant influence.

COMP $t$ statistic value is lower than $t$ table $(-2.023<-1.998)$ and the significance level is lower than $0.05(0.047<0.05)$. It means that there is significant influence of COMP on timeliness of financial statements reporting for sample of LQ45 Index companies period 2012 - 2014. This results support the results of research conducted by Owusu-Ansah (2000) which states that the complexity of the company's operations affect the timeliness of financial reporting. The level of complexity of the company's operations are based on the number of subsidiaries that a company has. This tend to influence the time of the auditor to complete the audit task, therefore affecting the timeliness of financial reporting by companies.

PROF t statistic value is lower than $t$ table $(-2.688<-1.998)$ and the significance level is lower than $0.05(0.009<0.05)$. It means that there is significant influence of PROF on timeliness of financial statements reporting for sample of LQ45 Index companies period $2012-2014$.

This results support the results of research conducted by Dyer and McHugh (1975) which found that companies that earn profits tend to be timely in submitting their financial statements, and vice versa if loss. The higher the profitability of a company then financial statements produced by the company contain good news. Companies that have good news in their report is likely to be more timely in publishing the financial statements. On the other hand, companies that have a low level of profitability then the financial statements will contain the bad news. Companies that have bad news in their report will likely not timely in publishing the financial statements.

SOLV $t$ statistic value is greater than $t$ table $(-1.858<-1.998)$ and the significance level is greater than $0.05(0.068>0.05)$. It means that there is no significant effect of SOLV on 
timeliness of financial statements reporting for sample of LQ45 Index companies period $2012-2014$.

In this research, it is found that half of the sample have solvency value above the average of all sample tested. Even though they have high solvency rate, they were still reporting the financial statement timely. It indicates that solvency does not have effect on timeliness of financial statement reporting for companies listed in LQ45 Index. Because of the company listed in LQ45 index is being the attention of investors, therefore they are trying to fulfill the needs of timely reported financial statement for investors.

This finding support the result of Owusu-Ansah (2000) and Amari and Jarboui (2013) that showed insignificant influence of solvency toward timeliness of financial statement reporting.

AUDIT $t$ statistic value is lower than $t$ table $(-2.039<-1.998)$ and the significance level is lower than $0.05(0.046<0.05)$. It means that there is significant influence of PROF on timeliness of financial statements reporting for sample of LQ45 Index companies period 2012 - 2014. This results support the results of research conducted by Owusu-Ansah and Leventis (2006) which found that companies using the service of big audit firm tend to release the financial statement faster. The size of the public accounting firm is differentiated into public accounting firms that enter the top four, in this case the Big Four and non Big Four public accounting firms, where the big four public accounting firm tend to more quickly complete the audit task they receive. Big Four public accounting firms generally have greater resources so that it can conduct audits more quickly and efficiently.

Out of company size, complexity of operation, profitability, solvency, and audit firm size used as independent variable in this research; only complexity of operation, profitability and audit firm size that shows significant result toward timeliness of financial statement reporting. The independent variable explained $26.3 \%$ of dependent variable. Meanwhile, company size and solvency cannot be a good predictor for timeliness of financial statement reporting.

\section{CONCLUSION}

Based on the analysis and result of the tests in the previous chapters, the conclusion of the influence of company size, complexity of operation, profitability, solvency, and audit firm size toward the timeliness of financial statements reporting for the companies listed in LQ45 index in Indonesia Stock Exchange period 2012 - 2014 is summarized as follows:

1. Hypothesis testing results indicate that Company size does not have significant influence toward the timeliness of financial statements reporting. This is shown by the significance value more than 0.05 , which is 0.511 .

2. With the significance value less than 0.05, which is 0.047 , the Hypothesis testing results indicate that Complexity of operation has significant influence toward the timeliness of financial statements reporting.

3. Hypothesis testing results indicate that Profitability has significant influence toward the timeliness of financial statements reporting, shown by the significance value less than 0.05 , which is 0.009 .

4. The significance value more than 0.05 , which is 0.068 , means the Hypothesis testing results indicate that Solvency does not have significant influence toward the timeliness of financial statements reporting.

5. Shown by the significance value less than 0.05, which is 0.046 , the Hypothesis testing results indicate that Audit firm size has significant influence toward the timeliness of financial statements reporting. 
6. Company size, complexity of operation, profitability, solvency, and audit firm size simultaneously contribute significant influence toward the timeliness of financial statements reporting. Independent variables are able to describe the timeliness of financial statements reporting up to $26.3 \%$. The rest $73.7 \%$ is determined by variables other than all variables used in this research.

However, this research has limitations. Results indicate little influence of the independent variables in influencing the dependent variable, which only amounted to $26.3 \%$ and the remaining $73.7 \%$ is influenced by other factors that are not included in the model, so there are many variables that affect the dependent variables, but are not included in this model. This research is limited to the company that are included in the LQ45 Index listed in Indonesia Stock Exchange period 2012 - 2014 that consist of heterogeneous industry. This make incompatibility of market capitalization to measure the company size because there is disproportionate in market share of companies from different industry.

In the future, researchers need to add other fundamental factors as independent variables, because it is very possible some fundamental factors that are not included in this study has a strong influence on share returns. Such as, Return on Asset (ROA), Debt to Equity ratio (DER), Total Assets, and many more. In the future, researchers need to add more research period. Thus, the result obtained later hopefully gives better explanation and show a better picture about the real condition of research subject. Also to provide better analysis for other interested users of the research. A ten years data or should prove adequate. In the future, researchers need to observing companies from specific type of industry to get more accurate picture of the results toward a specific industry. Such as, manufacturing, mining, service industry, and others.

\section{REFERENCES}

Al Daoud, K. A., Ku Ismail, K. N. I., \&Lode, N. A. (2014). The Timeliness of Financial Reporting among Jordanian Companies: Do Company and Board Characteristics, and Audit Opinion Matter?", Asian Social Science, 10(13), 191-201.

Amari, Mouna and Jarboui, Anis (2013). "Financial Reporting Delay and Corporate Governance: Evidence from Tunisia", International Journal of Information, Business and Management, 5(4), 32 - 46.

BAPEPAM (2011), "KEP-346/BL/2011: Concerning the Submission of Periodic Financial Statement for Issuers or Public Companies".

Bonsón, Enrique and Borrero, Cinta (2011). "Analysis of the Timeliness of Financial Statements Submitted by Companies of the Spanish Continuous Market", Review of Economic and Business Studies, 4(2), 63-86.

Boynton, W. C. \& Johnson, R. N. (2006). "Modern Auditing: Assurance Services and the Integrity of Financial Reporting, 8th Edition". Chicago: John Wiley \& Sons, Inc

Carslaw, C. A. P. N. and Kaplan, S. E. (1991). "An Examination of Audit delay: further Evidence from New Zealand", Accounting and Business Research, 22(85), 21-32.

Chambers, Anne E, and Pennman, Stephen H. (1984). "The Timeliness of Reporting and The Stock Price Reaction to Earnings Announcements", Journal of Accounting Research, 22(1), Spring.

Dyer IV, J. C. and McHugh, A. J. (1975). "The Timeliness of the Australian Annual Report”, Journal of Accounting Research, 13(2), 204-219.

Ghozali, Imam. (2013). Aplikasi Analisis Multivariate dengan Program SPSS. Semarang: BadanPenerbit - Undip

Indonesia Stock Exchange (2004), “Kep-307/BEJ/07-2004: Concerning the Sanction for 
Companies Who Were Late in Submitting the Financial Statements".

Owusu-Ansah, S. (2000). "Timeliness of Corporate Financial Reporting in Emerging Capital Markets: Empirical Evidence from the Zimbabwe Stock Exchange", Accounting and Business Research, 30 (3), pp. 241 - 254. Owusu-Ansah, S. and Leventis, S. (2006). "Timeliness of Corporate Annual Financial Reporting in Greece", European Accounting Review, 15(2), 273-287. 